It is likewise resistant to fused halides up to $800^{\circ} \mathrm{C}$. Above this temperature, crucibles deteriorate rapidly, chiefly through creep.

\section{Applications of the New Alloy}

The alloy can readily be rolled and drawn, and it can be deep-drawn and cupped without difficulty, it can be brazed to itself, or it can be brazed by a torch and oxygen-town gas, using fine gold as the filler metal.

It has been used for bushings for synthetic textile fibres in the presence of hydrogen sulphide at $50^{\circ} \mathrm{C}$.

The illustration on page 95 shows various laboratory crucibles with capacities from 30 to $75 \mathrm{ml}$. They were used to melt caesium iodide $\left(621^{\circ} \mathrm{C}\right)$, sodium iodide $\left(653^{\circ} \mathrm{C}\right)$ as well as eutectic mixtures of sodium fluoride and lithium fluoride (61 per cent $\mathrm{LiF}$, melting point $652^{\circ} \mathrm{C}$ ) and lithium fluoride/magnesium fluoride (53 per cent LiF, melting point $718^{\circ} \mathrm{C}$ ).
The illustration on page 97 shows a crucible $61 \mathrm{~cm}$ long and the sheath of the associated thermocouple. It is used for the continuous fusion at 650 to $750^{\circ} \mathrm{C}$ of molten aluminium fluoride based salt mixtures. It has a life of up to six months.

\section{References}

1 V. A. Nemilov, T. A. Vidusova, A. A. Rudnitskii and M. M. Putsikina, Akad. Nauk. USSR, Izv. Sekt. Plat., $1946,176-224$

2 A. A. Rudnitskii and V. P. Polyakova, Zh. Neorg. Khim., $1959,4,(10), 2304-2307$

3 A. A. Rudnitskii and A. N. Khotinskaya, Zh. Neorg. Khim., 1959, 4, (11), 2518-2524

4 E. Raub and G. Falkenburg, Z. Metallkunde, 1964, 55, (7), 392-397

5 A. S. Darling, Platinum Metals Rev., 1962, 6, (2), 60

6 E. Grafried, K. Protzmann, K. Ruthardt and H. Speidel, 100 Jahre Heraeus, Hanau, 1951, p. 43

7 Johnson Matthey, British Patent 1,112,766, 1966

8 G. L. Selman, M. R. Spender and A. S. Darling, Platinum Metals Rev., 1965, 9, (3), 92

9 G. L. Selman, M. R. Spender, A. S. Darling, Platinum Metals Rev., 1966, 10, (2), 54

\title{
Humidity Control Equipment
}

\section{GOLD GRIDS IN ELECTRONIC HUMIDISTATS}

Precise control of humidity is needed in buildings as diverse as offices, hospitals, schools, greenhouses, and textile plants. Humidistats for these purposes must offer fast response and close control of the relative humidity in a room by continuous sensing and appropriate operation of humidification or dehumidification equipment to the required level of relative humidity. Two new models have recently been developed by Honeywell's Commercial Division at Arlington Heights. They are three inches high, two inches wide and one and a half inches deep, and are thus suitable for wall mounting almost anywhere or can be modified for mounting on ducting.

Whereas the new pneumatic model is used for extensive control systems or where there is a danger of explosion, the new electronic model humidistat is suitable for smaller systems or where really fast and accurate response down to 1 per cent relative humidity is essential. The Micronik electronic humidistat uses a sensing element consisting of a thin plastic wafer covered with two grid patterns of gold lines and coated with lithium chloride, which is very sensitive to moisture. The grids are connected to separate terminals. When the humidity increases the area between the grid patterns becomes more conducting so that slightly more current flows from one to the other. This current, when amplified, operates the humidity control equipment.

Although these elements are so compact, each gold grid line is more than two feet long to give high

The Mikronik electronic humidistat made hy Honeywell incorporates a sensing element consisting of a plastic wafer with two gold grids on its surface. The element is mounted on the device as shown and is inserted within the slim case. The humidistat is suitable for the control of relative humidity in a wide variety of situations sensitivity and good response. Gold was chosen because of its high conductivity and excellent resistance to corrosive atmospheres. A dozen different sensing elements are available to cover relative humidity ranges from 5 to 95 per cent. To change the range of operation it is only necessary to pull out one element and plug in the one required.

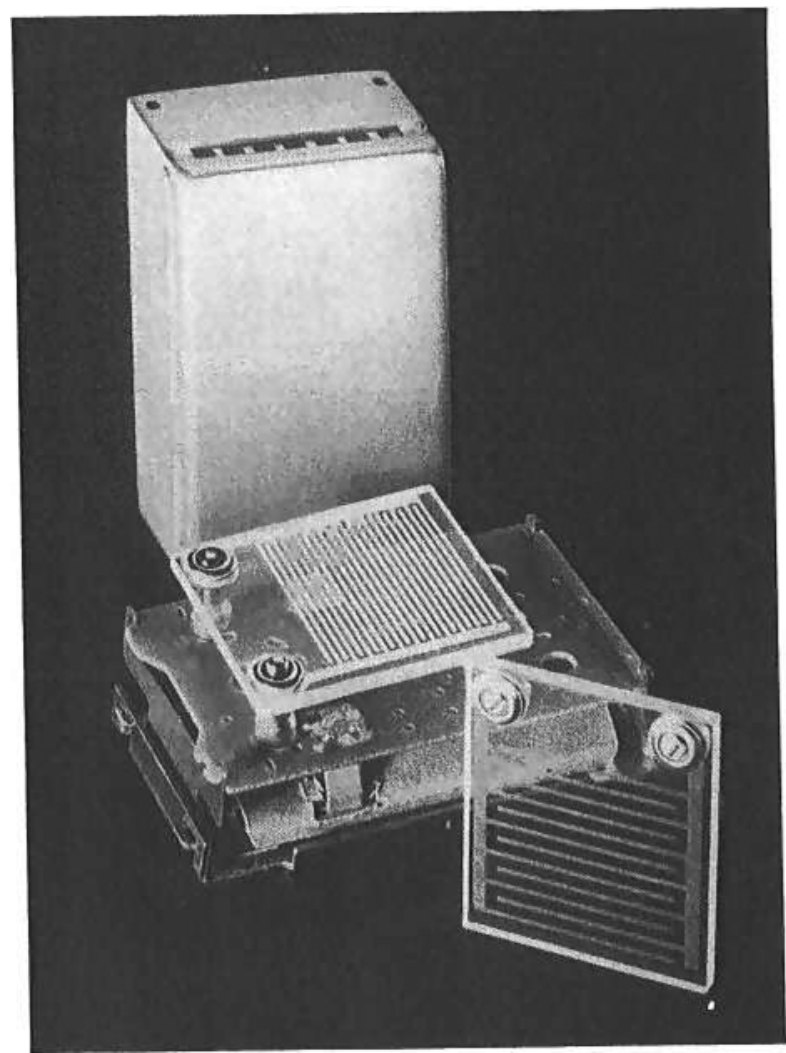

